\title{
Reverse Osmosis Removal of Heavy Metals from Wastewater Effluents Using Biowaste Materials Pretreatment
}

\author{
Bashkim S. Thaçi ${ }^{1}$, Salih T. Gashi* \\ ${ }^{1}$ University of Prishtina, Department of Chemistry, Republic of Kosova \\ ${ }^{2}$ Academy of Sciences and Arts of Kosova, Republic of Kosova
}

Received: 28 September 2017

Accepted: 17 December 2017

\begin{abstract}
The objective of this paper was to investigate the applicability of using biowaste materials prior to reverse osmosis treatment of water and wastewater effluents. The physico chemical properties of wheat bran, maize cob, and olive waste, and adsorption parameters such as metal concentration, adsorbent dose, contact time, and temperature of $\mathrm{Cd}(\mathrm{II})$ onto wheat bran are presented. The optimal parameters achieved in these experiment were used for sorptive removal of metal ions $\left(\mathrm{Pb}^{2+}, \mathrm{Zn}^{2+}, \mathrm{Cd}^{2+}\right.$, $\mathrm{Co}^{2+}, \mathrm{Mn}^{2+}, \mathrm{Ni}^{2+}$ ) from synthetic aqueous solution as well as from wastewater effluents of the mining flotation process. At short pretreatment time, retentate of sufficient concentration was achieved with above biosorbents for further treatment. It is used as feed for reverse osmosis tests. The high removal efficiency of metal ions from synthetic as well as wastewater samples was obtained with low-pressure heterogeneous asymmetric reverse osmosis membranes almost completely by this process.
\end{abstract}

Keywords: adsorption, biosorbents, heavy metals, pretreatment, reverse osmosis

\section{Introduction}

The rapid increase in industrial activities during the last decades has caused severe changes in the environment. This development has led to contamination of water resources with toxic contaminants such as heavy metals nutrient ions and dyes. Mining, mineral processing, and metallurgical operations (electroplating units, alloy manufacturing, etc.) generate a considerable amount of polluted water containing toxic heavy metals, which are almost persistent and non-degradable in nature, and which in turn cause adverse effects

*e-mail: salihtg@yahoo.com in the environment. Therefore, the treatment of these wastewaters becomes necessary before being discharged into the environment and river water streams, respectively. Several conventional methods (e.g., chemical precipitation, coagulation, sedimentation, adsorption, reduction, oxidation, solvent extraction, electrolytic extraction, evaporation, ion exchange, dialysis/electrodialysis, membrane processes, etc.) have been used to achieve effective and rapid removal of these environmental contaminants - particularly metal ions because of their toxic nature and high production cost, and limited or decreasing availability of metal deposits [1-2].

However, some of these techniques have constrains on their application, such as the high operating cost, energy-intensive use hazardous chemicals, and 
generating disposal of residual metal sludge, which can be a source of secondary contamination. On the contrary, sorption using biosorbents and biochars has seen significant advancement and is a promising technology for recovering heavy metals from water and wastewaters with subsequent recovery from them. A wide variety of biomaterials has been identified and examined extensively to generate low-cost sorbents for the treatment of water and wastewater such as peels of various fruits and vegetables, and bio-wastes from agricultural and industrial by-products like the production of cereals, rice husks, waste coffee, waste tea, sugar beet pulp, fungi, algae, etc.

Wheat bran was used as an adsorbent for removal of $\mathrm{Pb}$ (II) from wastewater [3], while waste olive cake, maize cob, and corn cob have been used for adsorption of $\mathrm{Zn}(\mathrm{II}), \mathrm{Ni}(\mathrm{II}), \mathrm{Mn}(\mathrm{II})$, and $\mathrm{Cd}(\mathrm{II})$ from aqueous solutions, respectively [4-8]. They were established as a potent adsorbent for heavy metal removal due to their good performance and large available quantities and excellent resources for environmental production purposes [911]. The performance of an aromatic polyamide (ES20) ultra-low-pressure reverse osmosis membrane for separating divalent $\left(\mathrm{Cu}^{2+}\right),\left(\mathrm{Ni}^{2+}\right)$ and hexavalent $\left(\mathrm{Cr}^{6+}\right)$ heavy metals from bulk solution was investigated. The rejection of heavy metals was found to be greater than $95 \%$ for tested membranes [12].

Synthetic wastewater samples containing $\mathrm{Cu}^{2+}$ and $\mathrm{Cd}^{2+}$ ions at various concentrations subjected to treatment by $\mathrm{RO}$ and NF in a laboratory showed high removal efficiency of the heavy metals. Thus by RO process we achieved ( $98 \%$ and $99 \%$ for $\mathrm{Cu}^{2+}$ and $\mathrm{Cd}^{2+}$, respectively). However, NF was capable of removing $\mathrm{Cu}^{2+}$ more than $90 \%$ of the time. The effectiveness of RO and NF membranes in treating wastewater containing more than one heavy metal was also investigated [13].

There is data about removing particular heavy metal ions by separate methods, but not much data about their combination exists. This paper aimed to represent the applicability of biowaste materials in natural form and their use in the pretreatment process before reverse osmosis treatment of water and wastewaters containing heavy metals

\section{Material and Methods}

The materials wheat bran, maize cob, and olive waste were washed with distilled water and dried $\left(80^{\circ} \mathrm{C}\right)$ for 20 hours. The dried samples were saved (0.1 mesh), and fractions of $>0.2 \mathrm{~mm}$ were used for experiments. The adsorbents used for examination of mineral content were prepared as follows: $1 \mathrm{~g}$ of dry adsorbents were burnt in a porcelain flask and the remaining ash was treated with aqua regia to dissolve the heavy metals (Tables 1-2). The stock solution of reagent grade $\mathrm{PbCl}_{2}$, $\mathrm{CdCl}_{2} \times \mathrm{H}_{2} \mathrm{O}, \mathrm{NiSO}_{4} \times 7 \mathrm{H}_{2} \mathrm{O}, \mathrm{ZnCl}_{2}, \mathrm{MnSO}_{4} \times \mathrm{H}_{2} \mathrm{O}$, and $\mathrm{Co}\left(\mathrm{NO}_{3}\right)_{2} \times 6 \mathrm{H}_{2} \mathrm{O}$ at a $30 \mathrm{mg} / \mathrm{dm}^{3}$ concentration was used in all experimental runs. The $5 \mathrm{~g}$ of above adsorbents
Table 1. Mass of adsorbents before and after ignition.

\begin{tabular}{|c|c|c|}
\hline Adsorbents & $\begin{array}{c}\text { Mass } \\
(\mathrm{mg})\end{array}$ & $\begin{array}{c}\text { Mass of ash after ignition } \\
(\mathrm{mg})\end{array}$ \\
\hline Wheat bran dm & 1000 & 78.14 \\
\hline Olive waste “ & 1000 & 69.76 \\
\hline Maize cob “ & 1000 & 84.80 \\
\hline
\end{tabular}

$\mathrm{Dm}=$ dry matter

Table 2. Metal content derived from adsorbent ash material.

\begin{tabular}{|cc|c|c|c|}
\hline \multicolumn{2}{|c|}{ Elements } & $\begin{array}{c}\text { Olive waste } \\
(\mathrm{mg} / \mathrm{g})\end{array}$ & $\begin{array}{c}\text { Wheat bran } \\
(\mathrm{mg} / \mathrm{g})\end{array}$ & $\begin{array}{c}\text { Maize cob } \\
(\mathrm{mg} / \mathrm{g})\end{array}$ \\
\hline $\mathrm{K}$ & $\mathrm{am}$ & 3.577 & 18.34 & 23.49 \\
\hline $\mathrm{Mg}$ & “ & 2.856 & 8.241 & 3.630 \\
\hline $\mathrm{Ca}$ & “ & 2.747 & 2.684 & 1.121 \\
\hline $\mathrm{Na}$ & “ & 1.234 & 2.744 & 2.219 \\
\hline $\mathrm{Zn}$ & “ & 1.065 & 1.516 & 0.946 \\
\hline $\mathrm{Pb}$ & “ & 0.673 & 0.767 & 0.731 \\
\hline $\mathrm{Mn}$ & “ & 0.088 & 0.101 & 0.452 \\
\hline $\mathrm{Ni}$ & “ & $<0.5 \mathrm{ppb}$ & $<0.5 \mathrm{ppb}$ & 0.976 \\
\hline $\mathrm{Cd}$ & “ & $<0.1 \mathrm{ppb}$ & $<0.1 \mathrm{ppb}$ & $<0.1 \mathrm{ppb}$ \\
\hline $\mathrm{Co}$ & “ & $<0.2 \mathrm{ppb}$ & $<0.2 \mathrm{ppb}$ & $<0.2 \mathrm{ppb}$ \\
\hline
\end{tabular}

$\mathrm{am}=$ ash material

was equilibrated with the above solution of known concentrations in a stopped Pyrex glass flask at $25^{\circ} \mathrm{C}$ in a thermostat with a mixer stirring for a $30 \mathrm{~min}$. A rather fast uptake occurs during the first $30 \mathrm{~min}$ of the adsorption process, followed by a slower stage as the adsorbed amount of elements reaches its equilibrium value. After that, the suspension was filtered and retentate was used as feed for reverse osmosis experiments. The concentration of metals in feed, after adsorption by sorbents and after reverse osmosis experiments, was analyzed by inductive coupled plasma optical emission spectroscopy (ICP-OS 2100DV). The procedure with an industrial sample from Trepça Mine flotation plants was the same as with synthetic samples.

The amount of adsorbed $\mathrm{Cd}(\mathrm{II})$ ions per gram wheat bran at equilibrium, qe (mg/g), and the removal percentage, $(\% \mathrm{~A})$, were calculated using the following equations:

$$
\begin{gathered}
\% \mathrm{~A}=C_{0}-C_{\mathrm{e}} / C_{0} \times 100 \\
\mathrm{q}_{\mathrm{e}}=\left(\mathrm{C}_{0}-\mathrm{C}_{\mathrm{e}}\right) \mathrm{V} / \mathrm{m}
\end{gathered}
$$

...where $\mathrm{C}_{0}$ and $\mathrm{C}_{\mathrm{e}}$ are the initial and equilibrium concentrations of $\mathrm{Cd}(\mathrm{II})$, respectively $\left(\mathrm{mg} / \mathrm{dm}^{3}\right) ; \mathrm{V}$ is the volume of $\mathrm{Cd}(\mathrm{II})$ solution $\left(\mathrm{dm}^{3}\right)$; and $\mathrm{m}$ is the weight of wheat bran used $(\mathrm{g})$. The composition of adsorbents was 
Table 3. Metal content in synthetic samples pretreated with biosorbents and treated by heterogeneous reverse osmosis membranes (batch 317 ) at pressure (1.76 MPa).

\begin{tabular}{|c|c|c|c|c|c|c|c|}
\hline & $\begin{array}{c}\text { Standard } \\
\text { solution } \\
\left(\mathrm{mg} / \mathrm{dm}^{3}\right)\end{array}$ & $\begin{array}{c}\text { Pretreated with } \\
\text { olive waste } \\
\left(\mathrm{mg} / \mathrm{dm}^{3}\right)\end{array}$ & $\begin{array}{c}\text { Treated with } \\
\text { memb. } \\
\left(\mathrm{mg} / \mathrm{dm}^{3}\right)\end{array}$ & $\begin{array}{c}\text { Pretreated with } \\
\text { wheat bran } \\
\left(\mathrm{mg} / \mathrm{dm}^{3}\right)\end{array}$ & $\begin{array}{c}\text { Treated with } \\
\text { memb. } \\
\left(\mathrm{mg} / \mathrm{dm}^{3}\right)\end{array}$ & $\begin{array}{c}\text { Pretreated with } \\
\text { maize cobs } \\
\left(\mathrm{mg} / \mathrm{dm}^{3}\right)\end{array}$ & $\begin{array}{c}\text { Treated with } \\
\text { memb. } \\
\left(\mathrm{mg} / \mathrm{dm}^{3}\right)\end{array}$ \\
\hline $\mathrm{Pb}$ & 30.41 & 2.943 & 0.040 & 2.778 & 0.043 & 3.539 & 0.032 \\
\hline $\mathrm{Cd}$ & 30.42 & 11.70 & 0.125 & 18.76 & 0.114 & 18.99 & 0.191 \\
\hline $\mathrm{Ni}$ & 29.51 & 11.00 & 0.195 & 17.54 & 0.209 & 17.36 & 0.234 \\
\hline $\mathrm{Zn}$ & 28.93 & 9.506 & 0.356 & 16.33 & 0.305 & 17.01 & 0.416 \\
\hline $\mathrm{Mn}$ & 30.69 & 18.68 & 0.179 & 21.62 & 0.138 & 20.44 & 0.182 \\
\hline $\mathrm{Co}$ & 29.23 & 13.92 & 0.207 & 16.91 & 0.216 & 17.54 & 0.273 \\
\hline $\mathrm{pH}$ & 5.75 & 5.20 & 6.10 & 5.30 & 6.10 & 5.20 & 6.00 \\
\hline
\end{tabular}

examined by an FTIR spectrophotometer (Shimadzu, FTIR $8400 \mathrm{~S}$ with $\mathrm{KBr}$ disc).

The retentate of biosorbent pretreatment was subjected to heterogeneous (cellulose acetate-coal) asymmetric reverse osmosis membranes (batch 317). The reverse osmosis film details and experimental reverse osmosis procedure is described elsewhere [14].

\section{Results and Discussion}

The wheat bran, maize cob, and olive waste were used as adsorbents in this study. Their characteristics and optimization factors influenced efficiency of heavy metal removal from water and wastewater as well as their use in the pretreatment step before reverse osmosis treatments are discussed.

\section{Characterizing Biosorbents}

The properties of materials used in the adsorption test are given in Tables 1-2. The presented results give different adsorbent contents of ash material and their mineral content in it. Mineral content - namely $\mathrm{K}, \mathrm{Na}$, and $\mathrm{Mg}$ - is higher in wheat bran and maize cob, while $\mathrm{Ca}$ is lowest in maize cobs and the contents of heavy metals $\mathrm{Pb}, \mathrm{Zn}, \mathrm{Mn}$, and $\mathrm{Ni}$, are higher in wheat bran and maize cob.

The spectra of adsorbents (wheat bran, maize cob, and olive waste) used in this paper recorded by FTIR spectroscopy are shown in Fig. 1. From the FTIR spectra it could be seen that there is a large number of functional groups characteristic for biosorbent used. Some major functional groups that predominate on the surface of resulting adsorbents are hydroxyl, carbonyl, aromatic ring, and amine.

\section{Effect of the Initial Sorbate Concentration and Contact Time}

Many adsorbents and many factors contribute to the efficiency of removing heavy metals. A lot of data exists about different adsorbents and methods for rejection of heavy metals from water and wastewater [15-16]. In the present work we examined the effect of initial $\left(\mathrm{Cd}^{2+}\right)$, concentrations at time intervals, constant adsorbent dose, temperature, and $\mathrm{pH}$.

The experiments were performed at two different initial cadmium concentrations $\left(15.0\right.$ and $\left.30 \mathrm{mg} / \mathrm{dm}^{3}\right)$ at time intervals, $25^{\circ} \mathrm{C}$, and $\mathrm{pH} 5.30$ for wheat bran. A rather fast uptake occurs during the first $30 \mathrm{~min}$ of the adsorption process, followed by slower stage as the adsorbed amount of elements reaches its equilibrium value and there does not seem to be much benefit from a stirring time longer than $30 \mathrm{~min}$. The equilibrium was independent of initial adsorbate concentration. Therefore, an equilibrium time of $30 \mathrm{~min}$ and adsorbate concentration of $30 \mathrm{mg} / \mathrm{dm}^{3}$ was selected for all further experiments.

\section{Pretreatment and Reverse Osmosis Tests}

The effects of removal of heavy metals from synthetic sample by biosorbents and heterogeneous asymmetric reverse osmosis membranes (batch 317) are given in Table 3.

It could be seen that synthetic samples containing heavy metals pretreated by biosorbents showed different removal efficiencies for resulting adsorbents and elements at near the same constant initial concentration,

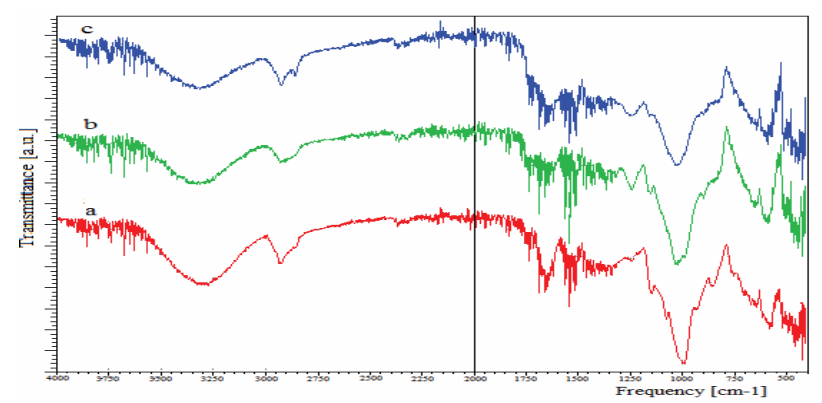

Fig. 1. FTIR spectra of: a) wheat bran, b) maize cobs, c) olive waste. 


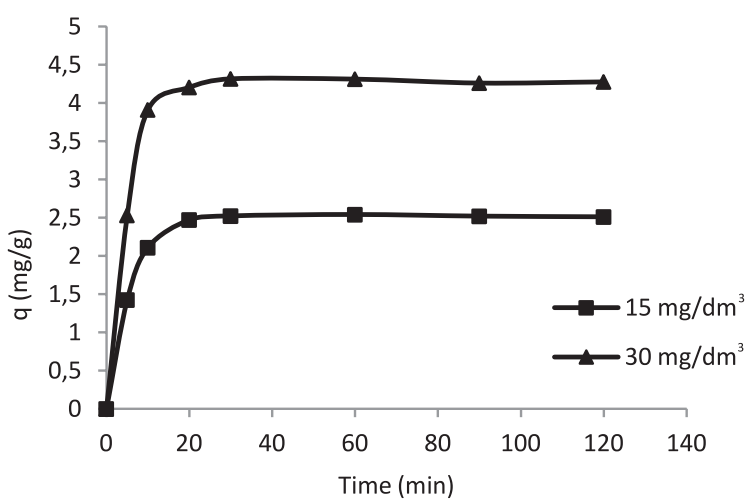

Fig. 2. Adsorption of $\mathrm{Cd}^{2+}$ of concentrations of $15.0 \mathrm{mg} / \mathrm{dm}^{3}$ and $30 \mathrm{mg} / \mathrm{dm}^{3}$ on wheat bran at time intervals constant adsorbent dose, $25^{\circ} \mathrm{C}$, and $\mathrm{pH} 5.30$.

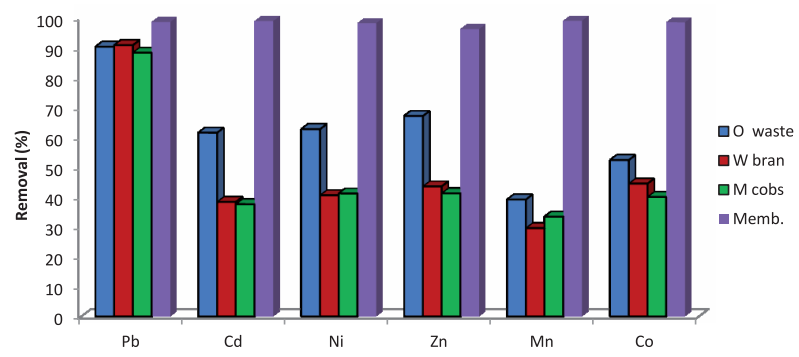

Fig. 3. Removal efficiencies (\%) of heavy metal from synthetic sample, pretreated by biosorbents and treated by heterogeneous reverse osmosis membranes (batch 317).

adsorbent dose and contact time, temperature, and $\mathrm{pH}$. The best removal efficiency of ions was achieved by olive waste (in comparison with wheat bran and maize cob) due to different surface areas, adsorption capacities, active sites of pores of adsorbent, nature of the ions, etc. The rejection order of elements was: $\mathrm{Pb}^{2+}>\mathrm{Zn}^{2+}>\mathrm{Ni}^{2+}$ $>\mathrm{Cd}^{2+}>\mathrm{Co}^{2+}>\mathrm{Mn}^{2+}$. These natural biosorbents contain a large number of functional groups (Fig. 1) that bind target metal ions from aqueous solutions through various processes such as passive electrostatic attraction or ion exchange, adsorption on the surface of adsorbent, surface precipitation/co-precipitation, or surface complexation, respectively [17]. The retentate of synthetic samples was used as feed for reverse osmosis experiments. These data are presented in Fig. 3.

The rejection of heavy metals is found to be $40-90 \%$ with biosorbents used in pretreatment step and near completely with low pressure $(1.76 \mathrm{MPa})$ heterogeneous asymmetric reverse osmosis membranes (batch 317).

The experimental results of wastewater samples of mine flotation plants (Trepça) conducted under the same conditions as synthetic sample are given in Table 4. The removal of heavy metals from mine flotation plants wastewater effluents (Trepça) for most elements is very high by the used bio-waste materials, which confirms the prediction that the adsorption is a preferable process for low-concentration heavy metals wastewaters [18-19]. The data (Table 4) also show that the rejection of heavy metals from industrial wastewater effluents by reverse osmosis membranes pretreated with resulting adsorbents under experimental conditions used in this study is almost complete $(99.8 \%)$.

\section{Conclusions}

Biowaste materials (wheat bran, maize cob, and olive waste) are a good source for the adsorption of heavy metals from wastewaters. Their performance data showed that short contact time, $\mathrm{pH}$, and temperature are very convenient for further treatment of industrial wastewaters by reverse osmosis without any agent addition. We also found that the biosorbents used in this study improve the applicability of heterogeneous asymmetric reverse osmosis membranes. They could be feasible and sustainable materials for pretreating wastewater prior to reverse osmosis treatment. The combination of these methods could be of potential use and look promising for complete recovery of heavy metals from water and wastewater, water reclamation, and reuse.

Table 4. Metal content in Trepça Mine flotation plant wastewater effluent samples pretreated with biosorbents and treated by heterogeneous reverse osmosis membranes (batch 317 ) at pressure (1.76 MPa).

\begin{tabular}{|c|c|c|c|c|c|c|c|}
\hline & $\begin{array}{c}\text { Feed } \\
\left(\mathrm{mg} / \mathrm{dm}^{3}\right)\end{array}$ & $\begin{array}{c}\text { Pretreated with } \\
\text { olive waste } \\
\left(\mathrm{mg} / \mathrm{dm}^{3}\right)\end{array}$ & $\begin{array}{c}\text { Treated with } \\
\text { memb. } \\
\left(\mathrm{mg} / \mathrm{dm}^{3}\right)\end{array}$ & $\begin{array}{c}\text { Pretreated with } \\
\text { wheat bran } \\
\left(\mathrm{mg} / \mathrm{dm}^{3}\right)\end{array}$ & $\begin{array}{c}\text { Treated with } \\
\text { memb. } \\
\left(\mathrm{mg} / \mathrm{dm}^{3}\right)\end{array}$ & $\begin{array}{c}\text { Pretreated with } \\
\text { maize cobs } \\
\left(\mathrm{mg} / \mathrm{dm}^{3}\right)\end{array}$ & $\begin{array}{c}\text { Treated with } \\
\text { memb. } \\
\left(\mathrm{mg} / \mathrm{dm}^{3}\right)\end{array}$ \\
\hline $\mathrm{Pb}$ & 0.034 & $<1 \mathrm{ppb}$ & $<1 \mathrm{ppb}$ & $<1 \mathrm{ppb}$ & $<1 \mathrm{ppb}$ & 0.009 & $<1 \mathrm{ppb}$ \\
\hline $\mathrm{Cd}$ & 0.025 & $<0.1 \mathrm{ppb}$ & $<0.1 \mathrm{ppb}$ & 0.007 & $<0.1 \mathrm{ppb}$ & 0.002 & $<1 \mathrm{ppb}$ \\
\hline $\mathrm{Ni}$ & 0.004 & $<0.5 \mathrm{ppb}$ & $<0.5 \mathrm{ppb}$ & $<0.5 \mathrm{ppb}$ & $<0.5 \mathrm{ppb}$ & $<0.5 \mathrm{ppb}$ & $<0.5 \mathrm{ppb}$ \\
\hline $\mathrm{Zn}$ & 0.153 & 0.024 & 0.002 & 0.069 & 0.002 & 0.062 & 0.004 \\
\hline $\mathrm{Mn}$ & 1.146 & 1.028 & 0.006 & 1.051 & 0.022 & 0.871 & 0.003 \\
\hline $\mathrm{Co}$ & 0.018 & $<0.2 \mathrm{ppb}$ & $<0.2 \mathrm{ppb}$ & 0.015 & 0.003 & $<0.2 \mathrm{ppb}$ & $<0.2 \mathrm{ppb}$ \\
\hline $\mathrm{pH}$ & 7.50 & 6.35 & 6.12 & 6.80 & 5.72 & 6.94 & 5.95 \\
\hline
\end{tabular}




\section{Conflict of Interest}

The authors declare no conflict of interest.

\section{References}

1. DAS N. Recovery of precious metals through biosorptionA rewiev. Hydrometallurgy. 103 (180), 2010.

2. DODSON J. R., PARKER H., MUNOZGARCIA A., HICKEN A., ASEMAVE K., FARMER TH., HE H., CLARK H. J., HUNT J. A. Bio-derived materials as a green route for precious critical metal recovery and reuse. Green Chemistry. 19 (51), 2015.

3. YASEMIN B., ZÜBEYDE B. Removal of $\mathrm{Pb}(\mathrm{II})$ from wastewater using wheat bran. J of Envir. Man. 78 (2), 2006.

4. FERNANDO A., MONTEIRO S., PINTO F., MENDES B. Production of biosorbents from waste olive cake and its adsorption characteristics for $\mathrm{Zn}^{2+}$ ion. Sustainability. 1 (2) 2009.

5. MUTHUSAMY P., MURUGAN S., SMITHA M. Removal of nickel ion from industrial waste water using maize Cobs. ISCA J. of Biological Sci. 1 (2), 2012.

6. HAGHDOOST G., AGHAIE H. Application of corn cob as a natural adsorbent for the removal of $\mathrm{Mn}$ (II) ion from aqueous solutions and thermodynamics. Ind. J. of Fund. and Appl. Life Sci. 5 (3), 2015.

7. MAHMOUD M. A. Thermodynamics and kinetics Studies of Mn(II) Removal from Aqueous solution onto Poweder Corn Cobs. J. Chromatogr. Sep. Tech. 6 (7), 2015.

8. SINGH K. K., SINGH A. K., HASAN SH. Low cost biosorbent wheat bran for the removal of cadmium from wastewater: Kinetic and equilibrium studies. Biores. Techn. 994 (97), 2006.
9. WANG J., CHEN C. Biosorbents for heavy metals removal and their future. Biotechn. Advanc. 195 (27), 2009.

10. RANGBHASHIYAM S., ANU N., SELVARAJU N. Sequestration of dye from textile industry wastewater using agricultural waste products as adsorbent. $\mathrm{J}$ of Environ. Chem. Eng. 1 (4), 2013.

11. FU F., WANG Q. Removal of heavy metal ions from wastewaters; review. J of Environ. Menag. 92 (3), 2011.

12. OZAKI H., SHARMA K., SAKTAYWIN W. Performance of an ultra low pressure Reverse osmosis membranes for separating heavy metal: effects of interference parameters. Desalination. 144 (1-3), 2002.

13. QDAIS H. A., MOUSSA H. Removal of heavy metals from waste water by membrane process: A comparative study. Desalination. 162 (2), 2004.

14. GASHI S. T., DACI N. M., PODVORICA F., SELIMI T., THAÇI B. Effect of the modification time of coal with aryldiazonium salts on performance of cellulose acetate-coal heterogeneous reverse osmosis membranes. Desalination. 240 (1), 2009.

15. TRIPATHI A., RAJAM M. R. Heavy Metal Removal from Wastewater Using Low cost Adsorbents. J. of Biorem \& Biodegrad. 6 (6), 2015.

16. DEMIRBAS A. Heavy metal adsorption agrobased waste materials, a review. J. Hazard. Mat.157 (220), 2008.

17. TAN X., LIU Y., ZENG G., WANG X., HU X., GU Y., YANG Z. Application of biochars for removal of pollutants from aqueous solutions. Chemosphere. 125 (70), 2015.

18. RAOUF A. M. S., RAHEIM A. R. M., Removal of Heavy metals from Industrial waste water by Biomass-Based, Materials: A Review. J. of Poll. effects \& Contra 5 (1), 2017.

19. PARK D., YUN S. J. The past present and future trends of biosorption. Biotechn an Bioprocess Engin. 15 (86), 2010. 
